\title{
Dental Nonmetric Traits in a Pre-Conquest Sample from Chubut Region of Patagonia, Argentina
}

\author{
Gabriel A. Bollini ${ }^{1}$, Carlos David Rodríguez-Flórez², and Sonia E. Colantonio ${ }^{3}$ \\ ${ }^{1}$ Cátedra de Antropología Biológica II, Facultad de Ciencias Naturales, Universidad Nacional de La \\ Plata - Argentina \\ ${ }^{2}$ Grupo de investigaciones ARQUEODIVERSIDAD, Universidad del Valle - Colombia, Departamento \\ de Antropología y Sociología, Universidad de Caldas - Colombia \\ ${ }^{3}$ Cátedra de Antropología Biológica y Cultural, Facultad de Ciencias Exactas, Físicas y Naturales, \\ Universidad Nacional de Córdoba - Argentina, Consejo Nacional de Investigaciones Científicas y \\ Técnicas (CONICET)
}

ABSTRACT Dental morphological trait expressions
have been used in anthropology and forensic sciences for
determinationofbiologicaland geographicalaffiliations.
The present study was carried out with a Chubut pre-
conquest sample from Patagonia, Argentina. 18 skulls
with partial dentitions from Chubut (Patagonia) were
analyzed. The ASU Dental Anthropology System was

Dental morphology has been used for determining biological and geographical affiliations. Dental variation has a heritablecomponent, seems to becaused by multiple genes, and is little influenced by environmental factors (Rodríguez-Florez et al., 2006). Dental morphology can provide insights into phenotypic group differences, and these may be suggestive of differences in genotypic affiliation (Varela and Cocilovo, 2000). Nonmetric dental traits seem to be controlled in part by genetics and are relatively free of sex- and age-bias (Scott and Turner, 1997). The analysis of biological relatedness using dental nonmetric traits has been helpful even in commingled samples when standardized procedures are followed (Ullinger et al., 2005). For these reasons, reconstruction of biological relationships among ancient human groups using teeth is an important research problem for South American bioarcheologists.

The present study was carried out with a Chubut human pre-conquest sample from Patagonia, Argentina, with the aim of exploring dental morphological dental patterns in this group (Fig. 1). Researchers describe the people of this region as a group of aboriginal populations named Chonik or Patagones del Sur (Tehuelches). These natives use an aboriginal dialect with "Tchon" linguistic affiliation (Canals Frau, 1953). The objective of this article is to describe the presence of 40 dental nonmetric traits in this pre-conquest sample from the Chubut.

\section{MATERIALS AND METHODS}

Pre-conquest human dental remains with reasonably reliable stratigraphic contexts are relatively rare from used to register the expression grade of all dental traits. In spite of small sample sizes, we can conclude that shovel shape (UI1, UI2), two lingual premolar cusps (UP1, UP2), and hypocone (UM1, UM2) frequencies suggest a Mongoloid (Sinodont) origin. Dental Anthropology 2008;21(2):50-53.

Argentina. Marcellino and Colantonio (2000) suggest a Late Period between 0 and 1,500 A.D for the present sample. The sample belongs to División de Antropología del Museo de Ciencias Naturales (La Plata, Argentina), and it is composed of 18 skulls with partial dentitions from Chubut: 1041, 1057, 1060, 1081, E1837, 1083, 1117, 1119, 1165, 1167, 1837, 1067, E1844, 1139, 1167, 1140, 1047, CR (Museum Catalogue references). Forty (40) dental nonmetric traits were recorded using the ASU Dental Anthropology System to register the expression grade of all dental traits (Turner et al., 1991). Recording all of the dental traits was difficult because of environmental issues such as antemortem tooth loss, missing mandibles, postmortem fractures, and pathologies (Fig. 2). Consequently, a dichotomous recording system was used, grouping grade expressions into either "presence" (1) or "absence" (0).

\section{RESULTS}

Trait frequencies are listed in Table 1 . It was impossible to adequately score three of the traits, namely paraconule (UM1) and the entoconulid (LM1, LM2). Values exceeding $70 \%$ were found for six traits - all in the upper arcade; these are shovel shape (UI1, UI2), two

Correspondence to: Carlos David Rodríguez-Flórez, Grupo de Investigaciones ARQUEODIVERSIDAD, Universidad del Valle - ColombiaDepartamento de Antropología y Sociología, Universidad de Caldas Colombia

E-mail: bioarqueologia@ucaldas.edu.co 

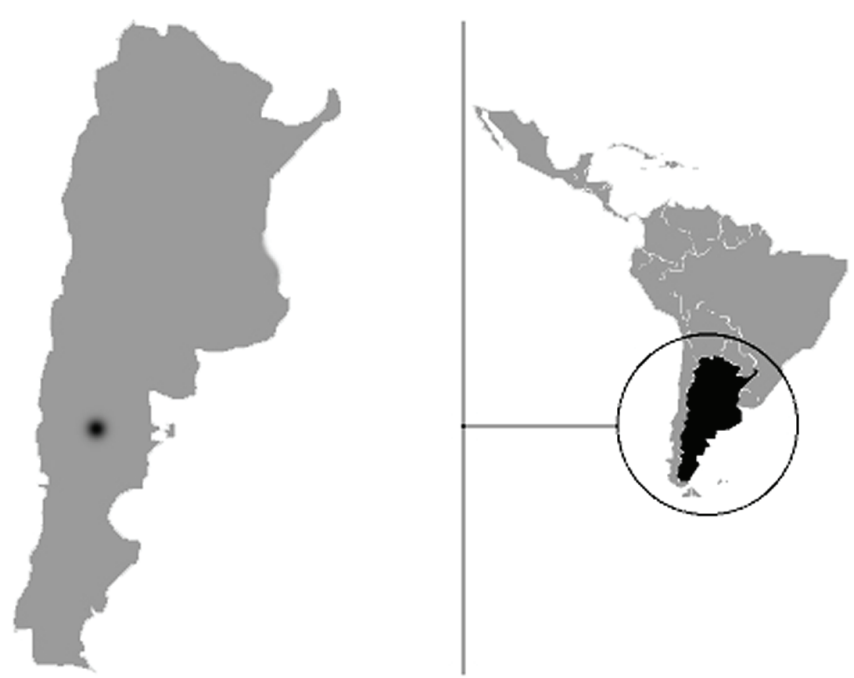

Fig. 1. Map of the Chubut region of Argentina..

lingual premolar cusps (UP1, UP2), and hypocone (UM1, UM2). Traits with frequencies between 10 and $69 \%$ were found for 12 traits: shovel shape (LI1, LI2, UC, LC), double shovel (UI1, UI2), tuberculum dentale (UI1, UI2, $\mathrm{UC}$ ), interruption groove (UI2), two lingual premolar cusps (LP2), and metaconulid (LM1). The remaining 19 traits did not occur in the sample: double shovel (UC, LI1, LI2, LC), tuberculum dentale (LI1, LI2, LC), interruption groove (UI1, LI1, LI2), two lingual premolar cusps (LP1), Carabelli trait (UM1, UM2), paraconule (UM2), metaconule (UM1, UM2), metaconulid (LM2), and protostylid (LM1, LM2).

\section{DISCUSSION}

For Argentinean pre-conquest samples, previous studies by Devoto and co-workers describe high

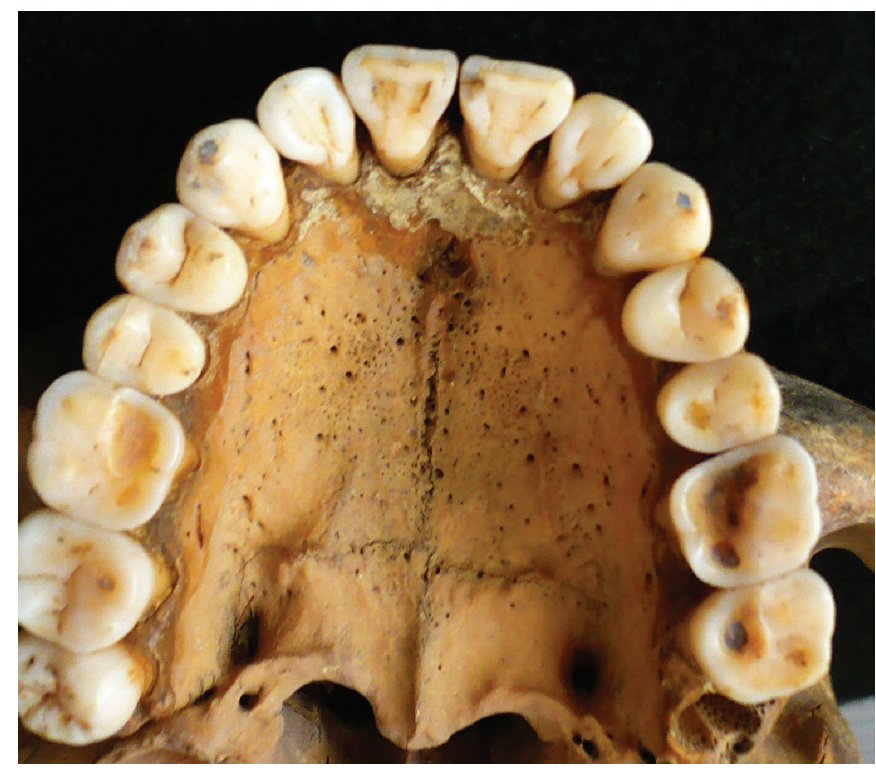

Fig. 2. Upper arcade of a Chubut skull (specimen 1083). frequencies of shovel shape in the maxillary incisors in early Atacama Indians (1968), pre-columbian Tastilian indians (1971), and a Northwestern Argentinean group from Salta Province (1968). Devoto describes shovel shape (UI1) in 13 specimens studied at $100 \%$. The high prevalence of dental shoveling is considered a prime component of the Mongoloid dental complex (Hanihara, 1968). For Devoto, in spite of his small samples, the data seem to be consistent enough to suggest that the specimens showed well-defined shovel-shaped maxillary incisors similar to well-typified Mongoloid races (DeVoto, 1971).

Pre-conquest samples from Tastil Region have shown similar distributions of some non-metric dental traits as double shovel shape UI2 (0.10), and tuberculum dentale UC (0.31) (Bollini et al., 2008). Comparably, the sample of Araucanos ethnic group exhibit similar distributions of shovel shape UI1 (0.85), and UI2 (0.71), double shovel shape UI1 (0.14), lingual cusp number UP1 and UP2 (1.00), hypocone UM1 (0.83), and metaconulid (0.11) (Bollini et al., 2007). These simple frequency comparisons are helpful in reinforcing the idea of early SinodontMongoloid ancestral groups in this region of Argentina. The frequency of shoveling in the Chubut sample studied here is near to these values, again suggesting a Sinodont pattern.

The use of morphological traits can involve problems of a methodological nature with small archeological samples. A necessary assumption is that dental trait expression is morphologically symmetrical between homologous teeth. In bioarcheology, estimating the frequency of a dental trait is influenced by the availability of samples due preservation, crown wear, and caries (Rodriguez-Florez and Colantonio, 2007). Some authors recommend scoring the higher grade of expression for each dental trait (Turner and Scott, 1977) or counting both the left and right sides for each individual (Haeussler et al., 1988).

The present investigation provides additional information for population dynamics that can help us infer the possible biological factors in the process of South American peopling into regional and temporal ranges on ancient Patagonia, Argentina (Marcellino, 2002).

\section{ACKNOWLEDGEMENTS}

We wish acknowledge to Cecilia Ferreira by helping in recording and laboratory assistance. This article is in memory of Dr. Jorge Eduardo Bollini (R.I.P.); see key references (Bollini et al. 2006, 2007, 2008).

\section{REFERENCES CITED}

Bollini GA, Rodríguez-Flórez CD, Colantonio SE, Mendez MG. 2006. Antropología Dental de una serie prehistórica de araucanos provenientes de la Patagonia Argentina. Revista de Arqueología 
TABLE 1. Dental nonmetric frequencies in the sample

\begin{tabular}{|c|c|c|c|c|c|c|}
\hline $\begin{array}{l}\text { Tooth } \\
\text { type }\end{array}$ & Trait & Dichotomy & Presence & Absence & $\mathrm{k} / \mathrm{n}$ & Frequency \\
\hline \multicolumn{7}{|c|}{ Maxillary Dentition } \\
\hline \multirow[t]{4}{*}{ UI1 } & Shovel shape & $0-3$ & $1-3$ & 0 & $10 / 11$ & 0.90 \\
\hline & Double shovel & $0-4$ & $1-4$ & 0 & $3 / 11$ & 0.27 \\
\hline & Tuberculum dentale & $0-3$ & $1-3$ & 0 & $4 / 11$ & 0.36 \\
\hline & Interruption groove & $0-1$ & 1 & 0 & $0 / 11$ & 0.00 \\
\hline \multirow[t]{4}{*}{ UI2 } & Shovel shape & $0-3$ & $1-3$ & 0 & $9 / 10$ & 0.90 \\
\hline & Double shovel & $0-4$ & $1-4$ & 0 & $1 / 9$ & 0.11 \\
\hline & Tuberculum dentale & $0-3$ & $1-3$ & 0 & $4 / 10$ & 0.40 \\
\hline & Interruption groove & $0-1$ & 1 & 0 & $2 / 11$ & 0.18 \\
\hline \multirow[t]{3}{*}{$\mathrm{UC}$} & Shovel shape & $0-3$ & $1-3$ & 0 & $3 / 7$ & 0.42 \\
\hline & Double shovel & $0-4$ & $1-4$ & 0 & $0 / 10$ & 0.00 \\
\hline & Tuberculum dentale & $0-3$ & $1-3$ & 0 & $2 / 10$ & 0.20 \\
\hline UP1 & Lingual cusp number & $1-3$ & $2-3$ & 1 & $11 / 11$ & 1.00 \\
\hline UP2 & Lingual cusp number & $1-3$ & $2-3$ & 1 & $9 / 9$ & 1.00 \\
\hline \multirow[t]{4}{*}{ UM1 } & Hypocone & $0-3$ & $1-3$ & 0 & $7 / 7$ & 1.00 \\
\hline & Carabelli complex & $0-4$ & $1-4$ & 0 & $0 / 7$ & 0.00 \\
\hline & Paraconule & $0-1$ & 1 & 0 & $-/-$ & - \\
\hline & Metaconule & $0-1$ & 1 & 0 & $0 / 1$ & 0.00 \\
\hline \multirow[t]{4}{*}{ UM2 } & Hypocone & $0-3$ & $1-3$ & 0 & $10 / 10$ & 1.00 \\
\hline & Carabelli complex & $0-4$ & $1-4$ & 0 & $0 / 9$ & 0.00 \\
\hline & Paraconule & $0-1$ & 1 & 0 & $0 / 4$ & 0.00 \\
\hline & Metaconule & $0-1$ & 1 & 0 & $0 / 6$ & 0.00 \\
\hline \multicolumn{7}{|c|}{ Mandibular Dentition } \\
\hline \multirow[t]{4}{*}{ LI1 } & Shovel shape & $0-3$ & $1-3$ & 0 & $1 / 6$ & 0.16 \\
\hline & Double shovel & $0-4$ & $1-4$ & 0 & $0 / 6$ & 0.00 \\
\hline & Tuberculum dentale & $0-3$ & $1-3$ & 0 & $0 / 6$ & 0.00 \\
\hline & Interruption groove & $0-1$ & 1 & 0 & $0 / 6$ & 0.00 \\
\hline \multirow[t]{4}{*}{ LI2 } & Shovel shape & $0-3$ & $1-3$ & 0 & $3 / 8$ & 0.37 \\
\hline & Double shovel & $0-4$ & $1-4$ & 0 & $0 / 7$ & 0.00 \\
\hline & Tuberculum dentale & $0-3$ & $1-3$ & 0 & $0 / 7$ & 0.00 \\
\hline & Interruption groove & $0-1$ & 1 & 0 & $0 / 8$ & 0.00 \\
\hline \multirow[t]{3}{*}{ LC } & Shovel shape & $0-3$ & $1-3$ & 0 & $2 / 7$ & 0.28 \\
\hline & Double shovel & $0-4$ & $1-4$ & 0 & $0 / 9$ & 0.00 \\
\hline & Tuberculum dentale & $0-3$ & $1-3$ & 0 & $0 / 9$ & 0.00 \\
\hline LP1 & Lingual cusp number & $0-3$ & $1-3$ & 0 & $0 / 8$ & 0.00 \\
\hline LP2 & Lingual cusp number & $0-3$ & $1-3$ & 0 & $4 / 8$ & 0.50 \\
\hline \multirow[t]{3}{*}{ LM1 } & Entoconulid & $0-1$ & 1 & 0 & $-/-$ & - \\
\hline & Metaconulid & $0-1$ & 1 & 0 & $1 / 4$ & 0.25 \\
\hline & Protostylid & $0-1$ & 1 & 0 & $0 / 10$ & 0.00 \\
\hline \multirow[t]{3}{*}{ LM2 } & Entoconulid & $0-1$ & 1 & 0 & $-/-$ & - \\
\hline & Metaconulid & $0-1$ & 1 & 0 & $0 / 2$ & 0.00 \\
\hline & Protostylid & $0-1$ & 1 & 0 & $0 / 9$ & 0.00 \\
\hline
\end{tabular}


Americana. Instituto Panamericano de Geografía e Historia (Mexico) 23:385-406.

Bollini GA, Rodríguez-Flórez CD, Colantonio SE, Mendez MG. 2007. Morfología dental de una serie prehistórica de araucanos provenientes de la Patagonia argentina y su relación biológica con otras poblaciones prehistóricas argentinas y del mundo. Int J Morphology, Sociedad Chilena de Anatomía (Chile) 24:705-712.

Bollini GA, Rodríguez-Flórez CD, Colantonio SE. 2008 Dental non-metric traits in a pre-conquest sample from Tastil region in Argentina, South America. Bull Int Assoc Paleodont 2:19-25.

Canals Frau S. Las poblaciones indígenas de la Argentina. Editorial Hyspamerica, 1953.

DeVoto FCH 1971. Shovel-shaped incisors in precolumbian Tastilian indians. J Dent Res 50:168.

DeVoto FCH, Arias NH, Ringuelet S, and Palma NH. 1968. Shovel-shaped incisors in a northwertern argentinean population. J Dent Res 47:820-823.

Haeussler AM, Turner CG II, Irish JD. 1988. Concordance of American and Soviet methods in dental anthropology. Am J Phys Anthropol 75:218.

Hanihara K. 1968. Mongoloid dental complex in the permanent dentition. Proc. VIIIth Internat Congress Anthropol Ethnol Sci I:293-300.

Marcellino AJ, Colantonio SE. 2000. Los cráneos aborígenes más antiguos de la Argentina: un ensayo clasificatorio. Tendencias actuales de la Investigación en la Antropología Física Española p 205-218.

Marcellino AJ. 2002. Los procesos de adaptación en el poblamiento aborigen de Sudamérica. Anales de la Academia Nacional de Ciencias de Buenos Aires, $p$ 9-26.
Rodriguea-Florez CD, Colantonio SE. 2007. Bilateral asymmetry of upper permanent dentition in six archaeological pre-conquest samples from Colombia, South America. Dental Anthropology 20:14-18.

Rodriguez-Florez CD, Fonseca GM, Villalba MT. 2006. Brief communication: Occurrence of an eighth cusp on primary second mandibular molars of a contemporary Argentinean child. Dental Anthropology 19:73-75.

Scott GR, Turner CG II. 1997. The anthropology of modern human teeth: dental morphology and its variation in recent human populations. Cambridge: Cambridge University Press.

Turner CG II, Scott GR. 1977. The dentition of Easter Islanders. In: Dahlberg AA, Graber TM, editors. Orofacial growth and development. The Hague: Mouton, p. 229-249.

Turner II CG, Nichol CR, Scott GR 1991. Scoring procedures for key morphological traits of the permanent dentition: The Arizona State University Dental Anthropology System. In: Kelley MA, Larsen CS, editors. Advances in dental anthropology. New York: Wiley-Liss Inc., p 13-31.

Ullinger JR, Sheridan SG, Hawkey DE, Turner II CG, Cooley R. 2005. Bioarchaeological analysis of cultural transition in the southern Levant using dental nonmetric traits. Am J Phys Anthropol 128:466-476.

Varela HH, Cocilovo JA. 2000. Structure of the Prehistoric population of San Pedro de Atacama. Curr Anthropol 41:125-132. 